\title{
PERLINDUNGAN HUKUM MEREK DAGANG DAN SANKSI
} PELANGGARAN PENGGUNAAN MEREK

\author{
Surya Rumiang Pasaribu ${ }^{1)^{*}}$, Hasyim ${ }^{2)}$ \\ 1) Fakultas Ekonomi, Universitas Negeri Medan \\ Email: srumiang@gmail.com \\ ${ }^{2)}$ Fakultas, Perguruan Tinggi \\ Email: mashasyim4@gmail.com
}

\begin{abstract}
Abstrak
Beberapa permasalahan yang diangkat dalam penulisan jurnal ini adalah perlindungan hukum bagi pemegang hak merek dan sanksi pelanggaran pengunaan merek menurut Undang-Undang Nomor 15 Tahun 2001 tentang Merek sebagai bentuk perlindungan terhadap merek-merek terdaftar. Adanya perlindungan hukum bagi pemilik merek yang sah dimaksudkan untuk memberikan hak yang sifatnya eksklusif (khusus) bagi pemilik merek (exclusive right) agar pihak lain tidak dapat menggunakan tanda yang sama atau mirip dengan yang dimilikinya baik untuk barang atau jasa yang sama atau hampir sama. Merek yang kuat ditandai dengan dikenalnya suatu merek dalam masyarakat, asosiasi merek yang tinggi pada suatu produk, persepsi positif dari pasar dan kesetiaan konsumen terhadap merek yang tinggi. Dan merek juga sangat memungkinkan konsumen untuk mengatur dengan lebih baik pengalaman tempat belanja mereka membantu mereka mencari dan menemukan keterangan produk. Adapun fungsi merek adalah untuk membedakan kepentingan perusahaan, penawaran dari semuanya. Telah diaturnya syaratsyarat yang harus dipenuhi oleh si pemohon dalam mengajukan permohonan pendaftaran merek tidak menghilangkan sama sekali terjadinya pelanggaran merek oleh pihak yang tidak bertanggung jawab
\end{abstract}

Keywords: Merk Dagang, Sanksi Pelanggaran, Hukum 


\section{PENDAHULUAN}

Dalam memproduksi sebuah produk/jasa, penjual pasti membutuhkan sebuah merek. Merek adalah nama atau simbol yang bersifat membedakan logo, cap/kemasan untuk mengidentifikasikan barang/jasa dari seorang penjual/kelompok penjual tertentu (David A. Aaker). Produk/jasa dapat menggunakan sebuah merek, apabila sudah terdaftar dan memiliki perlindungan hukum.

Perlindungan hukum di berikan agar mencegah penggunaan merek yang sama atau mirip dalam kegiatan perdagangan oleh pihak ketiga yang tanpa izin menggunakannya. Berthon, Hulbert dan Pitt (1999) menyatakan, fungsi identifikasi dari merek adalah untuk membedakan produk yang dapat memenuhi kepuasan konsumen dengan yang tidak. Perbedaan ini berguna bagi konsumen karena akan membantu mengenali suatu produk, mengurangi search cost dan menjamin suatu kualitas tertentu dari produk yang dibelinya. Sedangkan dari segi produsen, perbedaan ini memfasilitasi upaya promosi, segmentasi pasar, introduksi produk baru, brand loyalty dan pembelian kembali dari produk yang ditawarkan produsen.

Pada dekade ini perlindungan hukum di Indonesia ditandai dengan peningkatan gerakan perlindungan hukum terhadap Hak Milik Intelektual. Pemerintah Indonesia telah mengambil langkah-langkah guna meningkatkan perlindungan hukum dan pembinaan di bidang hak milik intelektual, termasuk hak atas merek, hak cipta dan hak paten.

Berdasarkan pada hal di atas, maka permasalahan utama yang diangkat dalam penelitian ini dirumuskan sebagai berikut : Bagaimanakah upaya perlindungan bagi pemegang merek menurut ketentuan UndangUndang Nomor 15 Tahun 2001 tentang Merek Serta Bagaimanakah sanksi bagi pelanggaran Merek..

\section{TINJAUAN PUSTAKA}

A. Merek

1. Ketentuan TRIPs Dalam Undang-Undang Merek

Penjelasan mengenai merek tentu tidak dapat lepas dari produk barang maupun jasa dalam komoditi perdagangan. Komoditi perdagangan yang ditandai dengan adanya suatu merek tentu memupunyai nilai jual yang secara ekonomis dapat membantu pendapatan
NIAGAWAN Vol 7 No 2 Juli 2018

masyarakat, individu ataupun badan hukum dalam memperoleh keuntungan. Merek yang diperdagangkan mempunyai berbagai macam bentuk dan keunggulan agar dapat menarik konsumen tertarik untuk membelinya. Persaingan dalam dunia perdagangan melalui merek di Indonesia tentunya telah diatur dalam Undang-Undang Merek yang telah beberapa kali mengalami perubahan, yaitu berawal dari Undang-Undang Nomor 21 Tahun 1961 tentang Merek Perusahaan dan Merek Perniagaan yang kemudian diubah menjadi Undang-Undang Nomor 19 Tahun 1992 tentang Merek, UndangUndang Nomor 14 Tahun 1997 tentang Merek dan terakhir diubah menjadi Undang-Undang Nomor 15 Tahun 2001 tentang Merek. Perubahan Undang-Undang Merek di Indonesia dari waktu ke waktu disesuaikan dengan konvensi internasional mengenai Hak Kekayaan Intelektual yang berhubungan dengan Merek, yaitu Trademark Law Treaty Tahun 1995. Trademark Law Treaty dalam perkembangannya dibumbui dengan adanya TRIPs (Trade-Related Aspects of Intellectual Property Rights), TRIPs merupakan instrument hukum internasional (Achmad Zen Umar, 2005 : 21), namun TRIPs bukanlah titik awal tumbuhnya konsep hak kekayaan intelektual. Berbagai Konvensi Internasional telah sejak lama dilahirkan, dan telah beberapa kali diubah. Yang signifikan dan menjadi dasar utama dari konsep Industrial Property adalah Paris Convention for the Protection of Industrial Property (Paris Convention), sedangkan untuk bidang copyright adalah Berne Convention for the Protection of Literaty and Artistic Works (Berne Convention) (Achmad Zen Umar, 2005 : 21). Tampak dari dua konvensi tersebut, secara tradisional hak kekayaan intelektual terbagi atas :industrial property, meliputi antara lain paten, merek dan desain industri; serta copyright and related rights. Prof. Michael Blakeney (Achamad Zen Umar, 2005 : 22), menguraikan cakupan hak kekayaan intelektual sebagai berikut : a. Literaty, artisticand scientific works; b. Performances of performing artists, phonograms and broadcasts; c. Inventions in all fileds of human endeavour; d. Scientific discoveries; e. Industrial designs; f. Trademarks, service marks and commercial namesand designations; $g$. Protection against unfair competition.

Hakikatnya TRIPs mengandung empat kelompok pengaturan.Pertama, yang mengaitkan hak kekayaan intelektual dengan konsep 
NIAGAWAN Vol 7 No 2 Juli 2018

perdagangan internasional.Kedua, yang mewajibkan negara-negara anggota untuk mematuhi Paris Convention.Ketiga, menetapkan aturan atau ketentuan sendiri. Keempat, yang merupakan ketentuan atas hal-hal yang secara umum termasuk upaya penegakan hukum yang terdapat dalam legislasi negaranegara anggota. Undang-Undang Merek terbaru Indonesia, yaitu Undang-Undang Nomor 15 Tahun 2001 tentang Merek sebagai pengubah dari Undang-Undang Merek lama (Undang-Undang Nomor 19 Tahun 1992 tentang Merek yang diubah menjadi Undang-Undang Nomor 14 Tahun 1997 tentang Merek) telah mengadopsi ketentuan-ketentuan dari TRIPs. Ketentuan-ketentuan dari TRIPs yang dituangkan ke dalam isi dari UndangUndang Nomor 15 Tahun 2001 tentang Merek adalah sebagai berikut (Achmad Zen Umar, 2005 : 71-75) :

a. Lingkup Merek dagang adalah setiap tanda atau kombinasi dari tanda yang mampu membedakan barang atau jasa dari satu badan ke badan usaha lain. Tanda tersebut meliputi kata, termasuk nama perseorangan, surat, angka, unsur-unsur figuratif dan kombinasi warna, juga kombinasi tanda. Negaranegara anggota juga dapat menetapkan pendaftaran berdasarkan perbedaan melalui penggunaan dalam hal tanda-tanda tersebut tidak cukup menimbulkan perbedaan barang-barang atau jasa tertentu. Bahkan negara-negara anggota dapat mensyaratkan bahwa tanda-tanda tersebut "be virtually perceptible". Ketentuan ini menyebabkan dimungkinkannya pendaftaran bentuk (shapes), bahkan aroma (smells) sebagai merek dagang.

b. Penggunaan Aktual Negara dapat menetapkan pendaftaran berdasarkan penggunaan aktual, namun penggunaan aktual merek dagang tidak boleh digunakan sebagai kondisi bagi pengajuan pendaftaran, dengan ungkapan lain permohonan pendaftaran tidak boleh ditolak semata-mata karena penggunaan yang direncanakan tidak terlaksana sebelum berakhirnya jangka waktu tiga tahun dari tanggal permohonan. Inilah yang menjadi dasar pengaturan nasional, termasuk Indonesia mengenai dapatnya hak atas merek dihapuskan jika tidak dipergunakan tiga tahun terus menerus. c. Sifat Produk Sifat produk, barang atau jasa tidak boleh menjadi alasan penolakan pendaftaran merek.

d. Pengumuman Negara mengatur agar sebelum didaftar, merek dagang dipublikasikan sehingga member kesempatan bagi pihak lain untuk menyampaikan keberatan atas permohonan pendaftaran merek tersebut. Ketentuan ini merupakan pelaksanaanprinsip keterbukaan, sebagai penyeimbang hak eksklusif yang dinikmati pemegang hak.

e. Hak yang diberikan Seperti pada bidang hak kekayaan intelektual yang lain, pemilik merek memiliki hak-hak eksklusif guna mencegah pihak lain, tanpa seizinnyauntuk menggunakan merek yang identik (identical) atau mirip (similar) bagi keperluan perdagangan, dan dalam hal demikian a likehood confudion shall be presumed, jadi kuncinya adalah identical, similar, dan likehood of confusion.

f. Merek Terkenal TRIPs, Art. 6bis Paris Convention mengenai merek terkenal (well known marks) diberlakukan terhadap barang atau jasa yang tidak sama dengan barang yang mereknya didaftarkan dengan ketentuan bahwa penggunaaan merek dagang dalam kaitannya dengan barang atau jasa tersebut menunjukan adanya hubungan antara barang atau jasa tersebut dengan barang yang merek dagangnya terdaftar dan dengan ketentuan pula bahwa pemilik merek terdaftar terganggu oleh penggunaan itu.

Kategori untuk menetapkan apakah suatu merek well-known, harus diperhitungkan pengetahuan akan merek terkenal di sekitar publik tertentu, termasuk pengetahuan di negara anggota sebagai akibat promosi merek dagang tersebut. Weel-known marks masih merupakan topik yang terus diperbincangkan sebab sampai saat ini belum ada definisi tentang well-known marks dan terpulang pada negara-negara anggota masing-masing.

Namun, telah ada guidelines yang dikeluarkan oleh WIPO yang sarinya menyangkut faktor-faktor dalam mempertimbangkan apakah suatu merek terkenal atau tidak. Pihak yang berwenang harus mempertimbangkan antarta lain hal-hal di bawah ini (Achmad Zen Umar, 2005 : 71-75):

a) Tingkat pengetahuan atau pengakuan mengenai merek tersebut dalam sektor publik yang bersangkutan; 
b) Masa, jangkauan dan daerah geografis dari penggunaan merek;

c) Masa, jangkauan dan daerah geografis dari promosi merek, termasuk pengiklanan dan publisitas serta presentasi pada pameran barantg-barang atau jasa merek tersebut;

d) Masa dan daerah geografis dari setiap pendaftaran dan setiap aplikasi pendaftaran samapai pada suatu timngkat sehingga merefleksikan penggunaan atau pengakuan merek;

e) Catatan dari penegakan hukum yang berhasil atas hak yang melekat pada merek sampai pada suatu tingkat di mana merek tersebut diakui sebagai merek terkenal oleh pejabat yang berwenang;

f) Nilai yang berkaitan dengan merek tersebut.

g) Masa Perlindungan Pendaftaran pertama dan tiap pengajuan masing-masing tidak boleh kurang dari 7 tahun dan dapat diperpanjang tanpa batas jumlah perpanjangan.

h) Persyaratan Penggunaan Jika suatu negara mensyaratkan penggunaan sebagai daftar pendaftaran, pendaftaran hanya dapat dibatalkan setelah periode paling kurang tiga tahun secara tidak terputus, kecuali adanya alasan halangan penggunaan yang ditunjukan oleh pemilik merek dagang.

i) Lisensi dan Pengalihan Negara dapat menetapkan persyaratan pemberi lisensi dan pengalihan merek dagang, namun lisensi wajib tidak dibenarkan.Lisensi wajib pernah terjadi di Amerika Serikat dalam kasus Rea Lemon dalam kaitan dengan kebijakan persaingan usaha.Perusahaan tergugat adalah satu perusahaan yang memiliki merek yang terkenal dan menguasai $75 \%$ pasaran untuk produk tersebut. Memparalelkan dengan lisensi wajib pada paten, dan agar tercapai persainagn yang sehat di bidang pemesanan lemon juice, Federal Trade Comission (FTC) mewajibkan perusahaan itu untuk memberikan merek ReaLemon selama sepuluh tahun kepada pihak lain dengan penawaran terbuka bagi pihak yang berminat. FTC menetapkan royaliti sebesar $1 \frac{1}{2} \%$. Lepas dari lisensi wajib ini, WTO tidak menerima konsep tersebut (Michael Blakeny, 1996 : 67).

Merek dalam penggunaannya digunakan sebagai daya pembeda barang atau jasa perusahaan dengan perusahaan lainnya yang sejenis. Dengan demikian merek adalah tanda pengenal barang atau jasa yang berasal dari
NIAGAWAN Vol 7 No 2 Juli 2018

produsen yang bersangkutan, dengan demikian merek secara tidak langsung juga menggambarkan reputasi suatu barang dan jasa dari si pemilik merek tersebut saat barang atau jasanya diperdagangkan.

Fungsi merek dapat dilihat dari sudut produsen, pedagang dan konsumen dari pihak produsen merek digunakan untuk jaminan nlai produksinya, khususnya mengenai kualitas, kemudaian pemakaiannnya. Dari pihak pedagang, merek digunakan untuk promosi barang-barang dagangannya guna mencari dan meluaskan pasarannya. Sedangkan dari pihak konsumen, merek digunakan untuk mengadakan pilihan barang yang akan dibeli. Jadi merek memberikan jaminan nilai atau kualitas dari barang dan jasa yang bersangkutan .Hal ini tidak hanya berguna bagi produsen pemilik merek tersebut, tetapi juga memberikan perlindungan dan jaminan mutu barang kepada produsen. Selanjutnya merek juga berfungsi sebagai sarana promosi bagi produsen atau pedagang atau pengusaha-pengusaha yang ingin menjual barang atau jasa yang bersangkutan.

Dengan adanya merek para pedagang memperluas jaringan pemasarannya dan juga dapat memepertahankan pasar tersebut.Selain itu merek juga dapat merangsang munculnya pertumbuhan indistri dan perdaganganyang sehat dan menguntungkan semua pihak.

Tuntutan pidana atas sengketa merek berdasarkan ketentuan Pasal 90 Undang-Undang Merek menyatakan bahwa, "Barang siapa dengan sengaja dan tanpa hak menggunakan merek yang sama pada keseluruhannya dengan merek terdaftar milik orang lain untuk barang dan/atau jasa sejenis yang diproduksi dan/atau diperdagangkan, dipidana dengan pidana penjara paling lama lima tahun dan denda paling banyak Rp 1.000.000.000,- (satu miliar).

Dimaksud dengan kata tanpa hak dalam Pasal 90 tersebut adalah merek yang digunakan tidak terdaftar dan sama pada keseluruhannya dengan merek terdaftar milik orang untuk barang dan/atau jasa sejenis sedangkan yang dimaksudkan dengan barang atau jasa sejenis dalam Pasal 90 dijelaskan bahwa kelompok barang dan/atau jasa yang mempunyai persamaan dalam sifat, cara pembuatan, dan tujuan penggunaannya. Seorang pemilik merek atau penerima lisensi (licensee) atas sebuah merek dapat menuntut seseorang yang tanpa izin, telah menggunakan merek yang memiliki persamaan pada pokoknya dengan merek orang 
lain yang berhak dalam bidang perdagangan dan jasa yang sama.

Banyaknya pelanggaran yang terjadi pada kasus merek maka ada beberapa cara untuk menyelesaikan permasalahan yang ada selain tuntutan secara perdata dan pidana yang dikarenakan kegagalan dalam proses mencapai suatu kesepakatan. Agar terciptanya proses penyelesaian suatu sengketa yang efektif, prasyarat yang harus dipenuhi oleh kedua belah pihak harus bersama-sama memperhatikan atau menjunjung tinggi hak untuk mendengar dan hak untuk di dengar.Ada 3 (tiga) faktor utama yang mempengaruhi proses penyelesaian sengketa, yaitu : a. Kepentingan (interest); b. Hak -hak (rights); dan c. Status kekuasaan (power)..

\section{METODE PENELITIAN}

Metode penelitian adalah cara ilmiah untuk mendapatkan data dengan tujuan dan kegunaan tertentu. Metode penelitian juga dapat diartikan sebagai cara-cara yang digunakan untuk mengumpulkan dan menganalisis data yang dikembangkan untuk memperoleh pengetahuan dengan menggunakan prosedur yang reliabel dan terpercaya. Dalam penelitian ini digunakan penelitian kepustakaan. Penelitian kepustakaan adalah serangkaian kegiatan yang berkenaan dengan metode pengumpulan data pustaka, membaca, dan mencatat serta mengolah bahan penelitian sehingga di dapat data yang di butuhkan.

\section{HASIL DAN PEMBAHASAN}

Merek merupakan salah satu wujud karya intelektual seseorang yang dilindungi oleh Undang-undang Merek di Indonesia. Merek merupakan tanda yang berupa gambar, nama, kata, huruf, angkaangka, susunan warna, atau kombinasi dari unsur-unsur tersebut sebagai identitas dari suatu produk (meliputi ruang lingkup, atribut, kualitas, dan penggunaan) kepada konsumen yang memiliki daya pembeda, yaitu membedakan sebuah produk barang atau jasa yang dihasilkan pihak yang satu dengan pihak yang lain (kompetitor) dengan kriteriakriteria yang ada di dalamnya. Merek tersebut lama- kelamaan dapat menjadi asset dari suatu perusahaan.

Menurut Suteti (2009: 98) Perlindungan Merek adalah salah satu bentuk kepastian hokum yang dibutuhkan investor, baik dalam maupun luar negeri. Setelah Indonesia meratifikasi Konvensi tentang Pembentukan Organisasi
NIAGAWAN Vol 7 No 2 Juli 2018

Perdagangan Dunia atau World Trade Organization (WTO) guna mengesahkan Undang-undang Nomor 7 Tahun 1994 tentang Pengesahan Persetujuan Pembentukan Organisasi Perdagangan Dunia atau Agreement Establishing the WTO, dilakukan pembenahan dalam berbagai peraturan perundang-undangan tentang Hak Kekayaan Intelektual di Indonesia.

Turut-sertanya Indonesia dalam era globalisasi menimbulkan tingkat persaingan yang semakin meninggi. Dalam persaingan usaha yang cukup ketat, timbul banyak kecurangan- kecurangan yang dilakukan oleh pelaku usaha untuk menjatuhkan kompetitor usahanya, misalnya dengan melakukan pemalsuan merek atau pemakaian merek milik orang lain secara tanpa izin. Hal tersebut dapat menimbulkan kerugian bagi pemilik merek yang sebenarnya apabila kualitas yang dijual tidak sama dengan kualitas yang asli. Selain itu juga menimbulkan kebingungan bagi masyarakat luas.

Pengertian merek dagang diatur dalam Pasal 1 angka 2 Undang- undang Nomor 15 Tahun 200 tentang Merek yang berbunyi sebagai berikut "Merek Dagang adalah Merek yang digunakan pada barang yang diperdagangkan oleh seseorang atau beberapa orang secara bersamasama atau badan hukum untuk membedakan dengan barang-barang sejenis lainnya" Hukum merek Indonesia menganut sistem "first to file", sehingga yang mendaftarkan pertama kali adalah yang berhak atas kepemilikan suatu merek. Agar merekmerek tersebut dapat dilindungi hukum, khususnya hukum merek di Indonesia, maka merek tersebut harus didaftarkan ke Departemen Kehakiman dan Hak Asasi Manusia - Direktorat Jenderal Hak Kekayaan Intelektual sehingga terdaftar dalam Daftar Umum Merek dan pemilik merek yang sebenarnya akan mendapat sertifikat merek sebagai tanda bukti hak/kepemilikan atas merek dagang produk. Bila tidak, maka pemilik merek yang sebenarnya akan sulit membuktikan haknya apabila suatu ketika merek tersebut digunakan pihak lain atau digugat oleh pihak lain. Mengenai hak atas merek tersebut diatur dalam Undang-undang Nomor 15 Tahun 2001 tentang Merek berbunyi sebagai berikut. Hak atas Merek adalah hak ekslusif yang diberikan oleh Negara kepada pemilik Merek yang terdaftar dalam Daftar Umum Merek untuk jangka waktu tertentu dengan menggunakan sendiri Merek tersebut 
atau memberikan izin kepada pihak lain untuk menggunakannya.

Di dalam rangka memberikan perlindungan hukum kepada pemilik terdaftar, hakim pengadilan negeri/pengadilan niaga dapat menetapkan penetapan sementara pengadilan. Pasal 80 Undang-Undang Nomor 15 Tahun 2001 menyatakan bahwa berdasarkan bukti yang cukup pihak yang haknya dirugikan dapat meminta hakim pengadilan niaga untuk menerbitkan surat penetapan sementara tentang : a. Pencegahan masuknya barang yang berkaitan dengan pelanggran hak merek. Ketentuan ini dimaksudkan untuk mencegah kerugian yang lebih besar pada pihak yang haknya dilanggar, sehingga pengadilan niaga diberi kewenangan untuk menerbitkan kewenangan sementara guna mencegah berlanjutnya pelanggaran dan masuknya barang yang diduga melanggar hak atas merek ke jalur perdagangan termasuktindakan importisasi. b. Penyimpanan alat bukti yang berkaitan dengan pelanggaran merek tersebut. Hal ini dimaksudkan untuk mencegah pihak pelanggar menghilangkan barang bukti Permohonan penetapan sementara diajukan secara tertulis kepada pengadilan niaga dengan persyaratan sebagai berikut :

a. Melampirkan bukti kepemilikan merek yaitu sertifikat merek atau surat pencacatan perjanjian lisensi bila pemohon penetapan adalah penerima lisensinya

b. Melampirkan bukti adanya petunjuk awal yang kuat atas pelanggaran merek

c. Keterngan yang jelas mengenai jenis barang dan atau dokumen yang diminta, dicari, dikumpulkan dan diamankan untuk keperluan pembuktian

d. Adanya kekhawatiran bahwa pihak yang diduga melakuka pelanggarnan merek akan dapat dengan mudah menghilangkan barang bukti

e. Membayar jaminan berupa uang tunai atau jaminan bank, yang besarnya harus sebanding dengan nilai barang atau nilai jasa yang dikenai penetapan sementara. Disamping ada gugatan perdata dalam hal pelanggaran merek dan persaingan curang, menurut Soenandar, Taryana (2007: 92) hukum mengancam barangsiapa yang melakukan kebohongan atau memberikan informasi bohong, atau pernyataan bohong, baik secara lisan maupun secara tertulis, atau bentuk kebohongan lainnya sehingga mendapat izin dari Kantor Paten untuk
NIAGAWAN Vol 7 No 2 Juli 2018 mendaftarkan merek dan nama perusahaan atau menyatakan dirinya sebagai pemilik dari merek atau nama perniagaan itu, atau menggunakan merek-merek tersebut.

\section{KESIMPULAN DAN SARAN}

Didalam perlindungan merek merupakan upaya yang dapat menjamin adanya kepastian hukum, sehingga dapat memberikan perlindungan hukum yang bersangkutan atau yang melakukan tindakan hukum. Pelaksanaan perlindungan hukum merek berdasarkan Undang-undang Nomor 15 Tahun 2001 tentang Merek, khususnya Pasal 3, yaitu mengenai pemberian hak eksklusif oleh negara kepada pemilik merek yang terdaftar dalam Daftar Umum Merek terhadap produk makanan belum dapat terlaksana dengan efektif.

Bagi mereka yang sudah memiliki sertifikat merek mengatakan bahwa mereka merasa lebih tenang dalam menjalankan usahanya ke depan. Selain itu, dengan adanya sertifikat merek, mereka merasa lebih mudah membuktikan hak atas kepemilikan merek yang mereka gunakan, sehingga dalam usahanya tidak lagi mencemaskan apabila suatu ketika ada yang menggugat merek yang mereka gunakan. Justru bagi mereka, sertifikat merek yang dimiliki bisa dijadikan alat untuk menggugat pihak lain yang dengan tanpa izin memproduksi dan menjual dengan merek yang sama sehingga merugikan konsumen yang sudah menjadi langganan.

Sertifikat merek merupakan tanda bukti bahwa merek tersebut telah didaftarkan dalam Daftar Umum Merek. Undang-undang Nomor 15 Tahun 2001 tentang Merek memberikan hak ekslusif kepada pemiliknya. Hak ekslusif ini memberikan jaminan perlindungan hukum atas merek yang mereka gunakan. Hak ekslusif ini melarang produsen lain menggunakan merek dengan tulisan ataupun gambar yang sama pada kemasannya. Akan tetapi hak tersebut tidak diberikan kepada para produsen yang belum memiliki sertifikat merek. Dalam kelanjutan usahanya, merek yang mereka gunakan bisa digunakan oleh orang lain. Didalam penyelesaian sengketa Undang-Undang Nomor 15 Tahun 2001 Tentang Merek telah menyediakan 2 (dua) sarana hukum, yang dapat dipergunakan sekaligus untuk menindak pelaku pelanggaran terhadap hak merek, yakni sarana hukum Pidana dan hukum Perdata. Selaian adanya pidana dan perdata juga penyelesaian dibidang hak merek dapat di lakukan diluar 
pengadilan melalui arbitrase atau altermative penyelesaian sengketa.

Terhadap pelanggaran hak merek si pelanggaran selain dikenakan sanksi pidana juga secara keperdataannyadapat dituntut oleh pemilik hak merek dan/atau pemegang hak merekyang haknya di langgar. Mereka dapat mengajukan gugatan untuk menuntut ganti rugi kepada pihak yang dianggap melanggar haknya, sehingga hak untuk mengajukan gugatan perdata sama sekali tidak mengurangi hak Negara sehingga untuk melakukan upaya penuntutan pidana atas pelanggaran Merek tersebut.

\section{REFERENSI}

Tim Lindsey (eds.). 2002. Hak Kekayaan Intelektual - Suatu Pengantar. Bandung: PT. Alumni.

Undang-undang Nomor 15 Tahun 2001 Tentang Merek. 2003. Jakarta : Sinar Grafika.

Undang-undang Perlindungan Hak Atas Kekayaan Intelektual. 2004. Jakarta : Citra Aditya Bakti.

Usman, Rachmadi. 2003. Hukum Hak atas Kekayaan Intelektual - Perlindungan dan Dimensi Hukumnya di Indonesia. Bandung : PT. Alumni.

Wahyuni, Erna, dkk. 2004. Kebijakan dan Manajemen Hukum Merek. Yogyakarta : Penerbit YPAPI. 